\title{
Generation of recombinant baculovirus expressing atoxic C-terminal CPA toxin of Clostridium perfringens and production of specific antibodies
}

Katia Forti ${ }^{1,2^{*}}$ D, Monica Cagiola ${ }^{1}$, Martina Pellegrini ${ }^{1}$, Lucia Anzalone ${ }^{1}$, Antonella Di Paolo ${ }^{1}$, Sara Corneli ${ }^{1}$, Giulio Severi ${ }^{1}$ and Antonio De Giuseppe ${ }^{1}$

\begin{abstract}
Background: Clostridium perfringens is the causative agent of several diseases and enteric infections in animals and humans. The virulence of $C$. perfringens is largely attributable to the production of numerous toxins; of these, the alpha toxin (CPA) plays a crucial role in histotoxic infections (gas gangrene). CPA toxin consists of two domains, i.e., the phospholipase $\mathrm{C}$ active site, which lies in the N-terminal domain amino acid (aa residues 1-250), and the Cterminal region (aa residues 251-370), which is responsible for the interaction of the toxin with membrane phospholipids in the presence of calcium ions. All currently produced clostridial vaccines contain toxoids derived from culture supernatants that are inactivated, mostly using formalin. The CPA is an immunogenic antigen; recently, it has been shown that mice that were immunized with the C-terminal domain of the toxin produced in E. coli were protected against C. perfringens infections and the anti-sera produced were able to inhibit the CPA activity. Monoclonal and polyclonal antibodies were produced only against full-length CPA and not against the truncated forms.
\end{abstract}

Results: In the present study, we have reported for the first time; about the generation of a recombinant baculovirus capable of producing a deleted rCPA toxin (rBacCPA250-363H6) lacking the N-terminal domain and the 28 amino acids (aa) of the putative signal sequence. The insertion of the $L 21$ consensus sequence upstream of the translational start codon ATG, drastically increases the yield of recombinant protein in the baculovirus-based expression system. The protein was purified by Ni-NTA affinity chromatography and the lack of toxicity in vitro was confirmed in $\mathrm{CaCo}-2$ cells. Polyclonal antibodies and eight hybridoma-secreting Monoclonal antibodies were generated and tested to assess specificity and reactivity. The anti-sera obtained against the fragment rBacCPA250363H6 neutralized the phospholipase C activity of full-length PLC.

Conclusions: The L21 leader sequence enhanced the expression of atoxic C-terminal recombinant CPA protein produced in insect cells. The monoclonal and polyclonal antibodies obtained were specific and highly reactive. The availability of these biologicals could contribute to the development of diagnostic assays and/or new recombinant protein vaccines.

Keywords: Clostridium perfringens, L21 leader sequence, Atoxic rBacCPA250-363H6, Affinity chromatography, Recombinant vaccines

\footnotetext{
*Correspondence: k.forti@izsum.it

'Istituto Zooprofilattico Sperimentale dell'Umbria e delle Marche "Togo

Rosati", Via G. Salvemini 1, 06126 Perugia, Italy

${ }^{2}$ Dipartimento di Medicina Veterinaria, Università degli Studi di Perugia, Via

San Costanzo 4, 06126 Perugia, Italy
}

(c) The Author(s). 2020 Open Access This article is distributed under the terms of the Creative Commons Attribution 4.0 International License (http://creativecommons.org/licenses/by/4.0/), which permits unrestricted use, distribution, and reproduction in any medium, provided you give appropriate credit to the original author(s) and the source, provide a link to the Creative Commons license, and indicate if changes were made. The Creative Commons Public Domain Dedication waiver (http://creativecommons.org/publicdomain/zero/1.0/) applies to the data made available in this article, unless otherwise stated. 


\section{Background}

Clostridium perfringens is an anaerobic, spore-forming bacterium that is widely distributed in the environment and is a part of the normal microbiota flora of the gastrointestinal tract of humans and animals. However, this ubiquitous, gram-positive, saprophyte, in certain circumstances, causes many enterotoxemic diseases and different forms of tissue damage (lamb dysentery, gas gangrene, food poisoning, and necrotic enteritis). Though $C$. perfringens does not invade healthy cells, it produces a wide range of potent extracellular toxins and enzymes that are responsible for the associated lesions and symptoms. Toxin production, which varies significantly among $C$. perfringens strains, is the basis for a classification system that, has been recently revised to include seven toxinotypes $(A, B, C, D, E, F, G)$, based upon the presence of genes encoding for alpha (CPA or PLC), beta (CPB), epsilon (ETX) and iota (ITX) toxins, and enterotoxin (CPE) and necrotic enteritis B-like toxin (NetB) [1]. However, this microorganism can produce at least 17 toxins in various combinations, including lethal toxins, such as perfringolysin $\mathrm{O}$ (PFO) and beta2 toxin (CPB2).

CPA is the most important virulence factor involved in human clostridial myonecrosis $[2,3]$ or histotoxic infections such as those causing gas gangrene $[4,5]$. The CPA encoding gene ( $c p a$ or $p l c)$ is situated in a stable region within the bacterial chromosome and CPA is produced by all $C$. perfringens strains, although the amounts produced by toxinotype A strains are usually higher than those produced by other toxinotypes [6]. The VirS/VirR-VR-RNA signal transduction cascade (QS systems) regulating the production of the toxin genes chromosomally located as cpa, pfoA and colA genes $[7,8]$. Recently studies stated that a down regulation of the QS regulatory systems is mediated by primary acidic metabolites and acidic environments, suggesting the possibility of $\mathrm{pH}$-controlled antivirulence strategies [9]. Alpha toxin is a $43 \mathrm{kDa}$ metallic enzyme comprised of 370 amino acids, which is secreted due to the presence of a signal peptide [10-12]. Three-dimensional analysis revealed that it consists of two domains, i.e., the catalytic $\alpha$-helical N-terminal zinc-binding domain (aa residues 1-250) that exhibited phospholipase C (PLC) and sphingomyelinase (SMase) activities, and the antiparallel $\beta$-sandwich $\mathrm{C}$-terminal calcium-binding region (aa residues 251-370), that influences the enzymatic activity of the N-terminal domain and is involved in the interaction between the toxin and membrane phospholipids $[6,13,14]$. CPA also has two flexible loops (central domain 55-93 aa and 132-149 aa) and its first domain contains a ganglioside (GM1a) binding site [14, 15].

Jepson et al. studied the difference between the C-terminal domains of $C$. perfringens and C. bifermentans and confirmed that the C-terminal domains of these proteins conferred different properties on the enzymatically active N-terminal domains of these proteins [16].

Both domains are immunogenic, but only the C-terminal domain stimulates a protective immune response [17, 18]. To determine which components of the C-terminal domain of the alpha-toxin were the strongest immunogens, Nagahama et al. immunized mice with various recombinant fragments produced in $E$. coli and evaluated their capacity to protect against $C$. perfringens infections [18]. Moreover, Goossens et al. demonstrated the protection afforded by antisera raised against the C-terminal domain of CPA toxin, concluding that the recombinant $\mathrm{C}$-terminal CPA could replace the full length CPA as a vaccine component [19]. The role of CPA in causing intestinal disease in mammals is controversial and poorly documented. In fact, though large amounts of CPA are detected in the faeces of naturally infected cattle, CPA is also present in the intestinal content of many clinically healthy animals [6]. The activity of CPA is highly complex, and it varies among cell types due to factors such as the ratio of phosphatidylcholine (PC) to sphingomyelin (SM) in the plasma membrane, and it is also influenced by toxin concentrations. This toxin was previously considered to act only locally on the cell membrane, but it has recently been shown that CPA has a cytotoxic effect at sublytic concentrations if it has been endocytosed and trafficked through the endolysosomal route [20]. Moreover, Takagishi et al. reported that the CPA toxin disturbed the innate immune system, by impairing granulopoiesis, inhibiting neutrophil differentiation, and decreasing the number of mature erythroblasts [21]. Therefore, despite the fact that CPA is the most studied $C$. perfringens toxin and the first bacterial toxin that had been shown to have an enzymatic activity [22], there are still some gaps in our knowledge regarding its molecular mechanism of action and its role as a component of the microbiota and in gastrointestinal diseases in humans and animals. Moreover, other interesting aspects include the antigenic architecture of CPA, availability of efficient diagnostic tools, and evaluation of its use in the production of a new generation of vaccines. Commercial diagnostic tests to detect the CPA toxin are available, but they are all very expensive and based on antibodies directed against the full-length 370 aa protein, and not against the truncated $\mathrm{C}$-terminal domain of the toxin that was produced only in prokaryotic systems.

The aim of the present study was to generate, for the first time, a recombinant baculovirus capable of producing an N-terminal truncated CPA protein of $C$. perfringens. Previous authors reported that a cis element of 21 bp (L21) derived from a $5^{\prime}$ untranslated leader sequence of a lobster tropomyosin cDNA, dramatically increased the expression levels of exogenous genes in baculovirusinfected insect cells [23]. L21 (AACTCCTAAAAAAC CGCCACC) has both the vertebrate Kozak sequence 
(CCGCCACC) and the A-rich sequence (TAAAAAA) found in the polyhedrin leader sequence, and it is well known that the A-rich sequence increased the expression level in Sf9 cells [23]. In order to improve the translation efficiency of the baculovirus-based expression system, two different cis regulatory elements, a $L 21$ consensus sequences and a selected Kozak sequence previously used in other studies [24] were inserted and the resultant levels of protein expression achieved were compared in this study. Monoclonal and polyclonal antibodies, that were obtained and directed against the purified non-toxic C-terminal rBacCPA250-363H6 recombinant protein, were tested to evaluate their reactivity and specificity in immunoblotting assays and their eventual use in home-made immunoenzymatic assays, which were able to detect native CPA from field strains of $C$. perfringens.

\section{Methods}

\section{Preparation of $C$. perfringens culture supernatant}

Broth culture supernatants of different $C$. perfringens toxinotypes were collected and evaluated to assess the levels of cytotoxicity and phospholipase $\mathrm{C}$ activity. The toxinotype of $C$. perfringens strains was determined by a colony multiplex polymerase chain reaction [25]. Bacteria were isolated and grown anaerobically on blood agar overnight at $37^{\circ} \mathrm{C}$. Then, a single colony of each isolate was inoculated into 5 $\mathrm{mL}$ of TGY broth (3\% tryptone, $2 \%$ yeast extract, $0.1 \%$ glucose, and $0.1 \%$ L-cysteine) and grown anaerobically at $37^{\circ} \mathrm{C}$ for 24-48 $\mathrm{h}$. The broth cultures were then centrifuged filtered $(0.22 \mu \mathrm{m})$ and stored at $-20^{\circ} \mathrm{C}$ for future use.

\section{Cloning of gene encoding N-terminal deleted rBacCPAH6 plasmids expressing in insect cell}

Bacterial genomic DNA was isolated from the culture supernatant of C. perfringens ATCC 13124, which contained the chromosomal gene cpa [26], using a QIAamp DNA Mini Kit (QIAGEN, GmbH, Germany) and stored at $-20^{\circ} \mathrm{C}$ until it was used as template to amplify the deleted recombinant forms of rBacCPAH6. Based on the DNA sequence of the CPA toxin in GenBank [26, 27], specific primer sets were designed (Table 1).

In order to increase recombinant protein expression levels and evaluate the importance of consensus leader sequences (Kozak and L21), three types of forward primers were designed that differed with regard to the nucleotide sequences present immediately upstream of the translational start codon ATG. In the first forward primer, no consensus sequence was present, while in the second and third forward primers, consensus Kozak and L21 sequences were inserted, respectively. Essentially, DNA fragments encoding the domain CPA279-363, was amplified from the previously extracted genomic DNA by PCR, using a Taq Polymerase AccuPrimePfx with high fidelity (Promega) and primers that caused the addition of EcoRI and AgeI sites at the 5' and $3^{\prime}$-ends of the product, respectively.

The constructs encoding the domains CPA279-370, CPA250-363 and CPA250-370 were generated as previously described bearing only the $L 21$ sequence.

The amplified products were analysed by $1 \%$ agarose gel electrophoresis, purified using the QIAquick PCR purification kit (QIAGEN), and cloned in the pOET2C6xHis transfer vector in frame with the 6xHis-tag, using appropriate restriction sites (EcoRI and AgeI). The resultant plasmid constructs were confirmed by sequence analysis. The recombinant baculoviruses expressing all the truncated $\mathrm{rBacCPAH} 6$ proteins were obtained by cotransfection of Sf21 insect cells with the constructs and with flashBAC DNA, as reported in the manufacturer's instructions of the flashBAC system (Oxford Expression Technologies, UK). Recombinant viruses titer (IFU/ml) were determined using the BacPAK Baculovirus Rapid Titer Kit (Clontech Laboratories, Inc).

\section{Expression of deleted rBacCPAH6 proteins}

The Spodoptera frugiperda insect cell line Sf21 (Thermo Fisher) was cultured in three different insect mediums, two serum-free mediums, HYQ SFX (HyClone), EX-cell 420 (Sigma) and Grace's medium (Thermo Fisher)

Table 1 Primer sequences of the recombinant truncated rBacCPAH6 proteins. The restriction sites and the start codons are underlined with a solid line, in bold the consensus leader sequences

\begin{tabular}{|c|c|}
\hline Primers & Nucleotide sequences \\
\hline rBacCPA 279-EcoRl ${ }^{\mathrm{b}}-\mathrm{F}$ & 5'-AAGAGAATTC $^{\mathrm{b}}$ TGTATATG $^{\mathrm{c}}$ GGAATCAAAACAAAGGATGT-3' \\
\hline rBacCPA 279Kozak $\boldsymbol{k}^{\mathrm{a}}-\underline{E}$ CoRl $^{\mathrm{b}}-\mathrm{F}$ & $5^{\prime}$-AAGAGAATTC ${ }^{\mathrm{b}}$ CAAA $^{\mathrm{a}} \underline{\text { ATG }}^{\mathrm{c}}$ GGAATCAAAACAAAGGATGT-3' \\
\hline 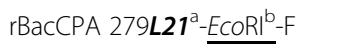 & 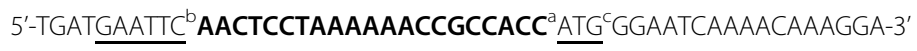 \\
\hline $\mathrm{rBaCCPA} 250 \mathbf{L 2 1}^{\mathrm{a}}-\mathrm{ECOR}^{\mathrm{b}}-\mathrm{F}$ & 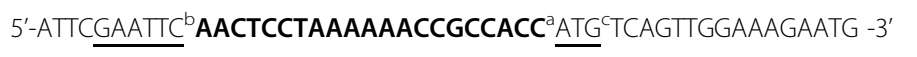 \\
\hline rBacCPA 363-Agel - R & 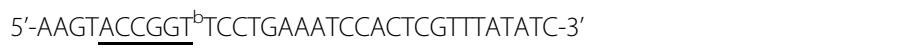 \\
\hline rBacCPA 370-Agel ${ }^{b}-R$ & 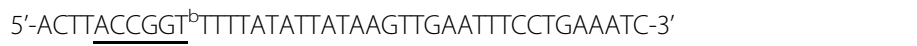 \\
\hline
\end{tabular}

${ }^{a}$ in bold $=$ consensus leader sequences

bith underline $=$ restriction site

${ }^{c}$ with underline $=$ start codon 
containing 10\% Foetal Bovine Serum (FBS) in cell culture flasks at $27^{\circ} \mathrm{C}$. The large-scale production of the recombinant proteins was performed after infecting Sf21 cells in serum free EX-cell 420 medium with the recombinant baculoviruses, according to the manufacturer's instructions. For estimate the expression level of protein with the different consensus leader sequences ( $L 21$ and Kozak) $7.5 \times 10^{6} \mathrm{Sf} 21$ cells were infected in $10 \mathrm{ml}$ of an EX-Cell 420 serum free medium with recombinant virus at a multiplicity of infection (MOI) of 2.0. After $72 \mathrm{~h}$ post-infection the infected cells were harvested and stored at $-20^{\circ} \mathrm{C}$ until further use.

\section{SDS-PAGE, Coomassie and Western blotting}

Protein levels were compared by lysing the infected and collected Sf21 cells in lysis buffer $(0.1 \mathrm{M}$ sodium phosphate buffer at $\mathrm{pH} 8,8 \mathrm{M}$ urea, $4 \mathrm{mM}$ DTT) in ice for 1 h. After centrifugation at $16,000 \times \mathrm{g}$ for $20 \mathrm{~min}$ at $4{ }^{\circ} \mathrm{C}$ the soluble fractions were quantified by Bradford method and an equal amount of all samples were mixed with $4 x N u$ Page sample buffer containing $100 \mathrm{mM}$ DTT and heated at $95^{\circ} \mathrm{C}$ for $10 \mathrm{~min}$. The denatured proteins were separated on a $12 \%$ SDS-PAGE precasting gel that was run for $1 \mathrm{~h}$ at $200 \mathrm{~V}$ and then staining with BioSafeCoomassie ${ }^{\circ}$ G-250 (Simply Blue SafeStain, Thermo Fisher Scientific) or electroblotted onto a PVDF membrane. The membranes were blocked for $3 \mathrm{~h}$ at room temperature with TBST buffer $(20 \mathrm{mM}$ Tris, 150 $\mathrm{mM} \mathrm{NaCl} \mathrm{pH} \mathrm{7.4} \mathrm{plus} 0.05 \%(\mathrm{v} / \mathrm{v})$ Tween 20$)$ containing $5 \%(\mathrm{w} / \mathrm{v})$ skimmed milk. After incubating the membranes overnight $(\mathrm{ON})$ with anti-His6-HRP conjugated MAbs, signals were detected using the SuperSignal West Pico Chemiluminescence kit (Thermo Fisher Scientific) with Alliance Mini HD9Western Blot Imaging System (Eppendorf).

\section{Purification of his-tagged deleted recombinant rBacCPAH6 proteins}

Proteins produced from baculovirus infected Sf21 cells were purified using a Ni-NTA His-select Nickel Affinity Gel (SIGMA-Aldrich) in denaturing conditions, according to the protocol provided by the manufacturer. The truncated $\mathrm{rBacCPAH} 6$ proteins that lacked the putative signal sequence encoding the first 28 amino acids were localized in the cell fraction. The cells were harvested by centrifugation and treated with the lysis buffer as previously described. Protein soluble fractions were recovered after the centrifugation of cellular lysates at $16,000 \times \mathrm{g}$ for $20 \mathrm{~min}$ at $4{ }^{\circ} \mathrm{C}$ after performing Ni-NTA. The purified proteins were eluted in buffers with a $\mathrm{pH}$ of 5 and 4.5, according to the manufacturer's instructions, and dialysed overnight in PBS buffer with $2 \mathrm{~K}$ MWCO slide-Alyzer cassette $G$ (Thermo Scientific). The protein concentration was determined using the Bradford protein assay reagent (Bio-Rad) and the purity was verified by resolving the protein using 12\% SDS-PAGE, followed by staining with Bio-SafeCoomassie ${ }^{\bullet}$ G-250 (Simply Blue SafeStain, Thermo Fisher Scientific). The integrity of the protein was established by western blotting, using an anti-His6-HRP conjugated MAb.

\section{CPA toxin biological activity with EYDT assay}

The phospholipase $\mathrm{C}$ (originally called lecithinase) activity of the recombinant CPA toxin and bacterial culture supernatants was assayed in an egg yolk agar well diffusion turbidity (EYDT) test [28]. A tryptose sulphite cycloserine (TSC) agar plate supplemented with $2 \%$ (vol/ vol) egg yolk was punched out using the back of a 20 $200 \mu \mathrm{l}$ pipette tip, to obtain holes with a diameter of 7 $\mathrm{mm}$. Twenty microliters containing from 0.5 to $5 \mu \mathrm{g}$ of the deleted rBacCPA250-363H6 protein and tested undiluted supernatant was added to each hole, along with $4 \mathrm{mM}$ of calcium chloride. Commercial full-length phospholipase C (PLC) toxin at $0.5,1,2,5 \mu \mathrm{g}$ was used as standard (P4039 Sigma). Plates were incubated at $37^{\circ} \mathrm{C}$ for $24 \mathrm{~h}$ and the diameters of the zones of opacity were measured using a calibre. The lecithinase activity $(\mathrm{U} / \mathrm{ml})$ was quantified using a standard curve, in which the log of concentration of the PLC standard was plotted against the radial diffusion diameter of turbidity [29].

\section{Cell culture}

Human colon carcinoma cells $(\mathrm{CaCo}-2)$ were purchased from $\mathrm{ATCC}^{\circ} \mathrm{HTB}-37^{\mathrm{Tw}}$. Cells were cultured in DMEM (Thermo Fisher) and supplemented with 15\% FBS, according to the instructions provided in the manual. All the incubation steps were carried out at $37^{\circ} \mathrm{C}$ in the presence of 5\% carbon dioxide [30].

\section{In vitro cytotoxicity assay}

The toxicity of clostridial CPA toxin toward cultured eukaryotic cells has been previously reported [31, 32]. The activity of the deleted recombinant protein rBacCPA250-363-H6, a full-length PLC protein (Sigma 4039) and that of culture supernatant of the C. perfringens strain was evaluated in the $\mathrm{CaCo}-2$ cell line. Briefly, $100 \mu \mathrm{l}$ of a solution, comprised of $3 \times 10{ }^{5}$ cells were seeded into each well of a 96 well plate and incubated at $37^{\circ}$ for 24 to $36 \mathrm{~h}$, until the cell monolayer exhibited almost $100 \%$ confluence. The medium was then removed from the wells and replaced with $100 \mu \mathrm{L}$ of MEM without phenol that contained the different samples to be tested. Different concentrations of the truncated rBacCPA250-363-H6 toxin and the PLC protein (10 ng, $100 \mathrm{ng}, 1 \mu \mathrm{g}, 5 \mu \mathrm{g}, 10 \mu \mathrm{g}, 20 \mu \mathrm{g}$, and $50 \mu \mathrm{g}$ ) were tested. The sterile bacterial culture supernatant was diluted 2fold from 1:2 to 1:8 (v/v) and added to wells in duplicate. The control wells were replaced only with MEM 
medium. Cytotoxicity was evaluated microscopically after 2 and $24 \mathrm{~h}$. Protein toxicity was established by determining the metabolic activity of cells using the MTS assay. Briefly, tetrazolium [3- (4,5-dimetil-2-il) -5- (3-carbossimetossifenil) -2- (4-sulfofenil)-2H-tetrazolium](MTS) reagent was added to cells, according the manufacturer's protocol (Promega) and the absorbance was measured at $490 \mathrm{~nm}$ after $2 \mathrm{~h}$. Cell viability was compared against untreated and positive controls, in order to assess the percentage of metabolically active cells [33]. The protein dose that caused $50 \%$ of cell mortality (CT50) was defined as the toxin concentration that reduced the optical density (OD) recorded at $490 \mathrm{~nm}$ by $50 \%$, against that of the untreated control.

\section{Generation of polyclonal and monoclonal antibodies}

Rabbit polyclonal antibody sera (PAbs) and monoclonal antibodies (MAbs) were obtained by the immunisation of rabbits and Balb/c mice, respectively, with the purified truncated recombinant rBacCPA250-363-H6 protein. The antibodies were developed from external custum service the PRIMM Biotech Company (Dosson di Casier, Treviso, Italy), that declare to follow good laboratory practices during experimentation and the standard operating procedures of the facility and D. LGS 4 March 2014, No. 26 (Italian transposition of Directive 2010/63 EU on the protection of animals used for scientific purposes). Rabbit and mouse sera and hybridoma supernatants were screened by indirect ELISA to assess the production level of specific antibodies. The MAb isotype of antibodies was determined according to the manufacturer's protocols (PRIMM Biotech SRL). The selected hybridoma cell lines were delivered to the lab and stored at $-80^{\circ} \mathrm{C}$ [34]. Monoclonal antibodies were produced in hybridoma tissue culture supernatant, in IMDM (Iscoves medium w/glutamax-I-Thermo Fisher) medium supplemented with $1 \%$ FBS, according to the procedure outlined in laboratory manuals $[35,36]$. MAbs were purified (rProtein A GraviTrap, GE Healthcare) and quantified using the Bradford method.

\section{Characterization of antibodies by Immunoblot assay}

Samples containing truncated rBacCPA250-363H6 $(0.1 \mu \mathrm{g})$, full-length PLC protein $(0.1 \mu \mathrm{g}), C$. perfringens, and $C$. septicum culture supernatants were denatured and separated by a $12 \%$ SDS-PAGE, as previously reported. The resolved proteins were transferred to a PVDF membrane and blocked by incubating it with TBST containing $5 \%(\mathrm{w} / \mathrm{v})$ non-fat milk for $2 \mathrm{~h}$ at room temperature (RT). The membrane was washed and incubated $\mathrm{ON}$ at $4{ }^{\circ} \mathrm{C}$ with the PAbs and each of the MAbs, that were derived from distinct hybridoma cell lines, after diluting them in TBST containing 3\% skim milk. A commercial rabbit anti-phospholipase $\mathrm{C}$ polyclonal antibody (CRE-CABT-L1999- Star Fish) was also tested for comparing the results with those observed for the developed PAbs. After four washes, the membrane was incubated with secondary HRP conjugated, anti-mouse, or anti-rabbit antibodies, according to the nature of the sample tested. The antibody-antigen interactions were highlighted with the SuperSignal West Pico Chemiluminescence kit (Thermo Scientific).

\section{In vitro neutralization of CPA toxin biological activity}

The ability of the antisera and developed MAbs to neutralize the phospholipase $\mathrm{C}$ activity of full-length PLC toxin was assessed in EYDT assay. The negative control was obtained from mouse sera before carrying out immunization. Serially diluted serum (from 1:2 to 1: 960) and an increasing concentration of MAb (from 5 to $120 \mu \mathrm{g}$ ) were pre-incubated at $37^{\circ} \mathrm{C}$ for $1 \mathrm{~h}$ with a constant amount of PLC toxin $(1 \mu \mathrm{g})$ and $4 \mathrm{mM}$ of calcium chloride, and PLC activity was then measured in egg yolk lipoproteins, as described previously. After incubation, the variations in radial diffusion diameter were measured and compared to those of the control.

\section{In vitro neutralization cytotoxicity assay}

The ability of a specific monoclonal antibody (MAb 318F11B7) and antisera raised against rBacCPA250$363 \mathrm{H} 6$ to neutralize the cytotoxicity of full-length PLC toxin and C. perfringens culture supernatant (C-5560/18) was established by an in vitro assay. Briefly, the sera and $\mathrm{MAb}$, were diluted at different concentrations and preincubated for $1 \mathrm{~h}$ at $37^{\circ} \mathrm{C}$, with the PLC toxin present at a concentration corresponding to its CT50 $(50 \mu \mathrm{g} / \mathrm{ml})$ value Then the solution was applied, in triplicate, to wells with a confluent cell monolayer, to assess each condition that needed to be examined. After $16-24 \mathrm{~h}$, the $\mathrm{CaCo}-2$ cell viability was measured by the MTS assay.

\section{Results \\ Production and purification of the truncated $\mathrm{rBacCPAH} 6$ proteins}

To establish the effect of the different consensus leader sequences on the protein expression grade and optimal growth conditions, an initial investigation was performed with $\mathrm{rBacCPA} 279-363 \mathrm{H} 6$ protein, which was the first truncated recombinant toxin to be generated (Fig. 1).

Three recombinant plasmids, i.e., pOET2-CPA279363H6, pOET2-KozakCPA279-363H6, and pOET2L21CPA279-363H6, which differed with regard to the presence/absence of Kozak and $L 21$ leader sequences upstream of the start codon, were constructed. Using general DNA cloning protocols and a PCR strategy, the $\mathrm{N}$-terminal domain, which included the putative signal sequence (first 28 aa) of the cpa toxin gene, was removed and part of the domain (from 279 to 363 aa) was 


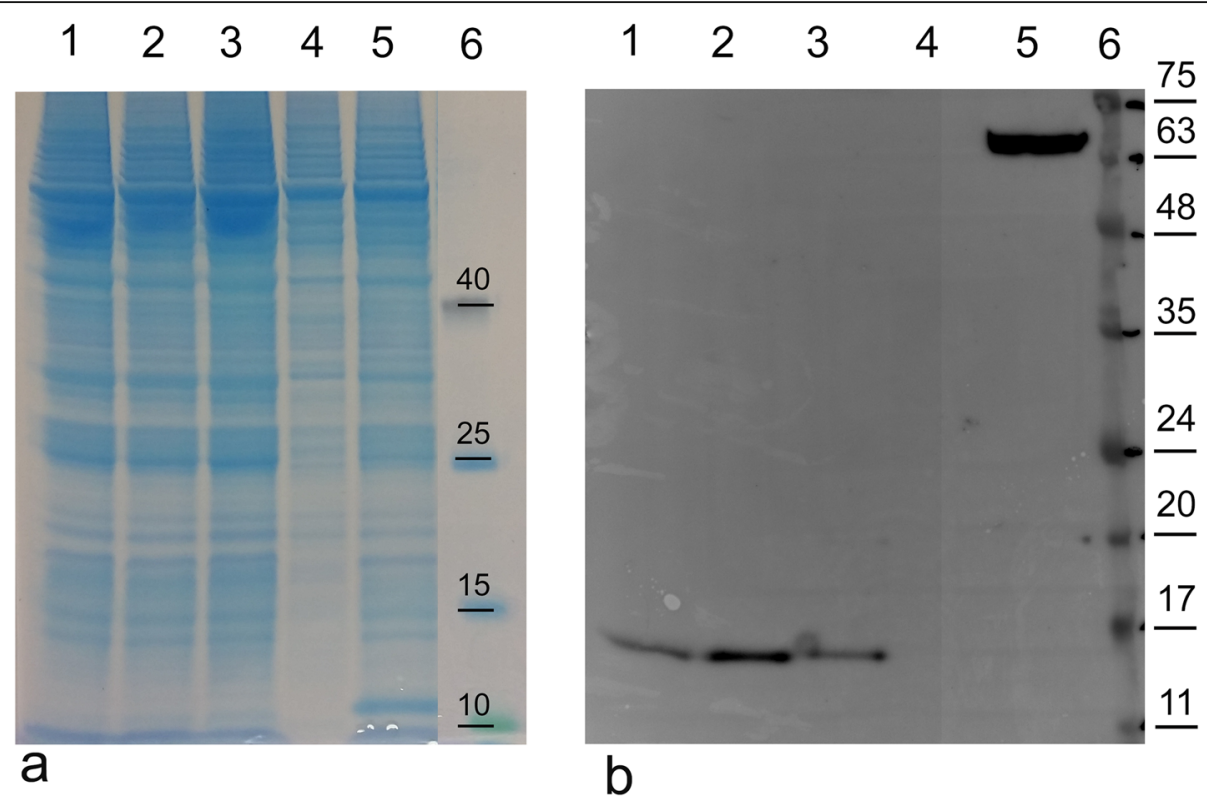

Fig. 1 Analysis of the C-terminal fragment rBacCPA279-363H6 with different consensus leader sequences. $7.5 \times 10^{6} \mathrm{Sf} 21$ cells were infected in 10 $\mathrm{ml}$ of an EX-Cell 420 serum free medium with recombinant virus at a multiplicity of infection (MOI) of 2.0. After $72 \mathrm{~h}$ post-infection the infected cells were collected and lysed and the total protein of this preparation was quantified by the Bradford assay. Equal quantity of the cellular lysate of each sample was loaded electrophoresed on 12\% SDS-PAGE gels and at the same time both (a) stained with Coomassie blue and (b) analysed in Western blot using an anti-His6-HRP conjugated MAb. Lane 1: rBac CPA279-363H6 without a leader sequence; lane 2: rBacCPA279-363H6 with L21 sequence; lane 3: rBacCPA279-363H6 with Kozaks sequence; lane 4: non-infected Sf21 cells (negative control); lane 5: Sf21 cell infected with recombinant baculovirus containing a target gene His tagged but not related with CPA (His6 positive control); lane 6: protein markers (the molecular weight bands in $\mathrm{kDa}$, are reported on the right). The infections was repeated more than three times and the figure represents the highest-quality picture obtained

cloned in frame with 6xHis tag into the pOET2_C$6 \mathrm{XHis}$ vector. The analysis of the nucleotide sequences, performed for all the constructs obtained with these cloning procedures, showed a perfect identity in the nucleotide composition (data not shown). The proteins were expressed in Sf21 insect cells and analysed by western blotting, usinganti-His6-HRP conjugated MAbs. The MAbs revealed the presence of immunoreactive bands with a molecular weight of approximately $11 \mathrm{kDa}$ in the cellular extract, as expected after the elimination of the signal sequence (Fig. 1). Moreover, a different expression level has been shown according to the regulatory sequences; Kozak and especially the $L 21$ sequence induced an enhancement in protein expression levels. The comparison of the level of rBacCPA279-363H6 produced in three different growth mediums, i.e., Grace's medium supplemented with 10\% FBS, HyClone-SFX, and Ex-cell 420 has highlighted the fact that the use of the Ex-cell 420 culture medium resulted in the best performance and guaranteed that the protein production process would be more efficient (Fig. 2).

The recombinant rBacCPA279-363H6 protein was generated on a large scale in EX-cell 420 medium, using a baculovirus with the $L 21$ signal sequence and it was purified using the Ni-NTA system under different experimental conditions.
Several attempts for protein purification were made, to obtain the protein in native and denaturing conditions; however, a satisfactory yield and level of purity could not be achieved (data not shown). Hence, three new truncated recombinant proteins, longer than the first (from 250 to 370 aa), were designed, i.e., CPA279-370, CPA250-363 and CPA250-370 and were expressed in insect cells. All the baculoviruses generated contained the $L 21$ signal sequence upstream of the start codon and the corresponding proteins were produced in the serum free Ex-Cell420 medium in equivalent infection conditions (Fig. 3). Western blotting analysis with anti-His6-HRP conjugated MAb revealed that the molecular weights of immunoreactive bands representing the presence of rBacCPA279-363H6, rBacCPA279-370H6, rBacCPA250-363H6, and rBacCPA250-370H6 were approximately $11,12,15$, and $16 \mathrm{KDa}$, respectively. Under the same infection conditions, the first and second recombinant proteins were expressed at very low levels (Fig. 3b, lane 2-4), as compared to the expression levels of the two other recombinant toxins (Fig. 3b, lane 1-3). Therefore, based on these results, the baculovirus containing the $L 21$ sequence that expressed the truncated recombinant protein rBacCPA250$363 \mathrm{H} 6$ was selected for use in subsequent studies. Ni-NTA purification was performed in both native and denaturing reducing conditions; however, a satisfactory yield, purity, and 


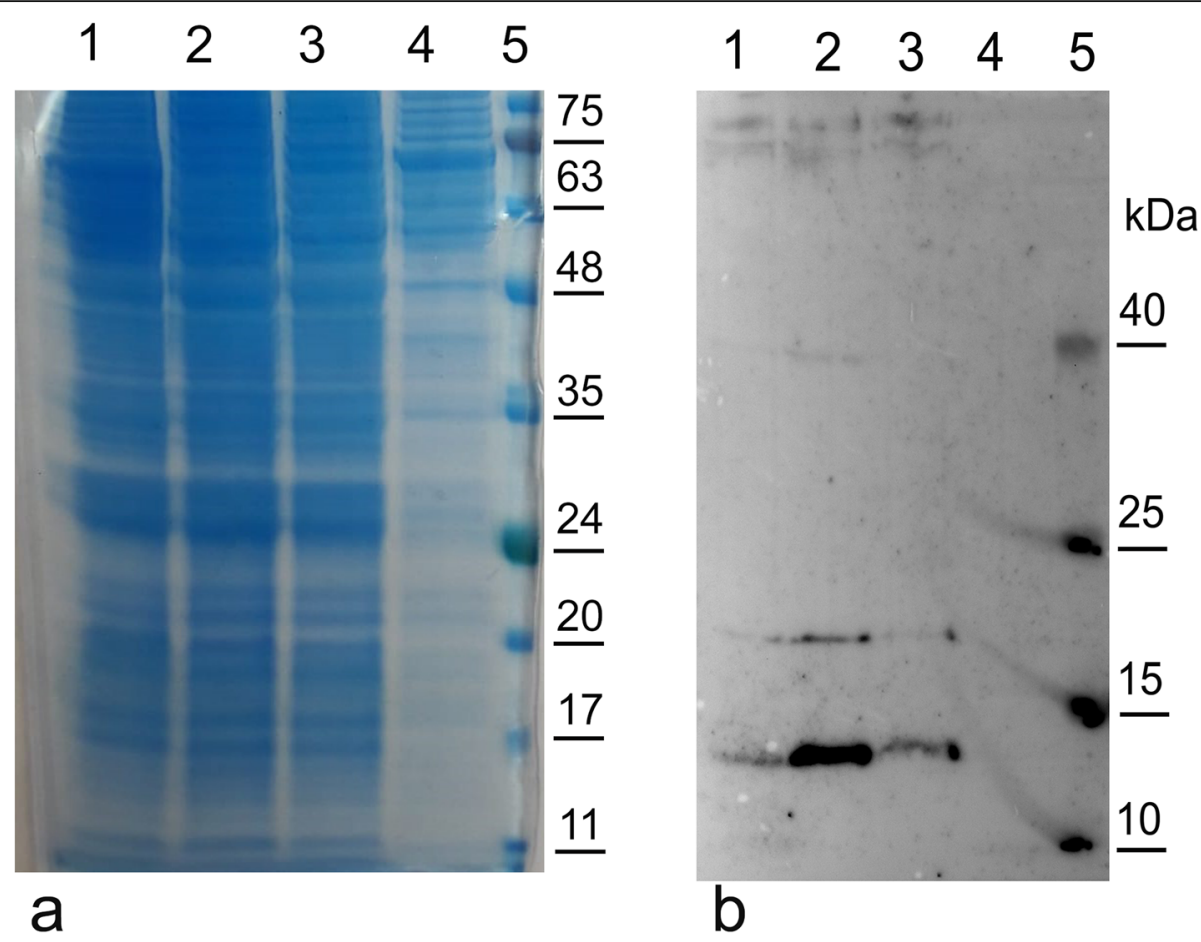

Fig. 2 Western blot analysis of the C-terminal fragment rBacCPA279-363H6 in different media. Sf21 cells were infected with rBacCPA279-363H6 with $L 21$ sequence in different media and the cellular lysates harvested $72 \mathrm{~h}$ post-infection and quantified by the BioRad assay. Equal quantity of the cellular lysate of each sample was loaded electrophoresed on 12\% SDS-PAGE gels and simultaneously both (a) stained with Coomassie blue and analysed (b) in Western blot using an anti-His6-HRP conjugated MAb. Lane 1: recombinant protein in Grace's medium supplemented with 10\% FBS; lane 2: recombinant protein in EX-cell 420 serum free medium; lane 3: recombinant protein in HYQ-SFX in serum free medium, lane 4: cellular lysate of Sf21 uninfected cells (negative control); lane 5: protein markers with the molecular weight bands in kDa reported on the right

protein concentration was achieved only with the latter. Figure 4a shows the process of purification of recombinant rBacCPa250-363H6 and Fig. 4b the eluition fractions before and after dialisys step, using Coomassie stained SDS-PAGE, and the specificity and integrity of the protein, which were determined using immunoblot analysis with anti-His6-HRP conjugated MAb (Fig. 4b). In conclusion, after the dialisys step a degree of purity that was $\geq 85 \%$ was obtained with a yield of $4 \mathrm{mg}$ for $10^{9}$ insect cells.

\section{In vitro cytotoxicity}

The cytotoxic activity of the rBac250-363CPAHis6 protein was tested in parallel with that of the full length PLC protein and C. perfringens culture in CaCo- 2 cells using the MTS assay. No morphological changes were observed, as compared with the untreated control cells, after cells were exposed to doses of $0.1,1,10,50$, and $100 \mu \mathrm{g} / \mathrm{ml}$ of rBac250-363CРAH6 (Fig. 5a). However, morphological changes, including the rounding up of cells, were observed in cells exposed to 10, 50, and $100 \mu \mathrm{g} / \mathrm{ml}$ of PLC toxin (data not shown).

The MTS assay results revealed that the viability score of CaCo- 2 cells treated with up to $50 \mu \mathrm{g} / \mathrm{ml} \mathrm{rBacCPA250-}$
$363 \mathrm{H} 6$ was $100 \%$, while that of cells treated with $100 \mu \mathrm{g} /$ $\mathrm{ml}$ of recombinant protein was $88 \%$ (Fig. $5 \mathrm{a}$ ). Notably, the presence of the PLC protein lowered cell viability to $80 \%$, when a dose of $10 \mu \mathrm{g} / \mathrm{ml}$ was used, and to $33 \%$, when a dose of $100 \mu \mathrm{g} / \mathrm{ml}$ was used (Fig. 5a). Interestingly, the undiluted culture supernatant of $C$. perfringens C5560/18 induced similar cytotoxic effects as those observed using $100 \mu \mathrm{g} / \mathrm{ml}$ of PLC and led to a drastic reduction in cellular metabolic activity, as compared to that in untreated control cells (Fig. 5b). No cytotoxic activity was observed for the truncated rBacCPA250-363H6 protein at concentrations till to $50 \mu \mathrm{g} / \mathrm{ml}$; instead, for the full-length PLC, cytotoxicity was observed at a concentration that was as low as $10 \mu \mathrm{g} / \mathrm{ml}$, and the CT50 was determined at $50 \mu \mathrm{g}$ $/ \mathrm{ml}$.

\section{In vitro neutralization of CPA toxin biological activity}

The capability to break down the lecithin present in the egg yolk and the resulting white halo around the colonies was used as a measure of CPA biological activity. The truncated recombinant rBacCPA250363H6 protein did not exhibit any lecithinase activity at all the tested concentrations (Fig. 6). However, on 
$\mathbf{a}$
$\mathrm{N}$-domain
C-domain
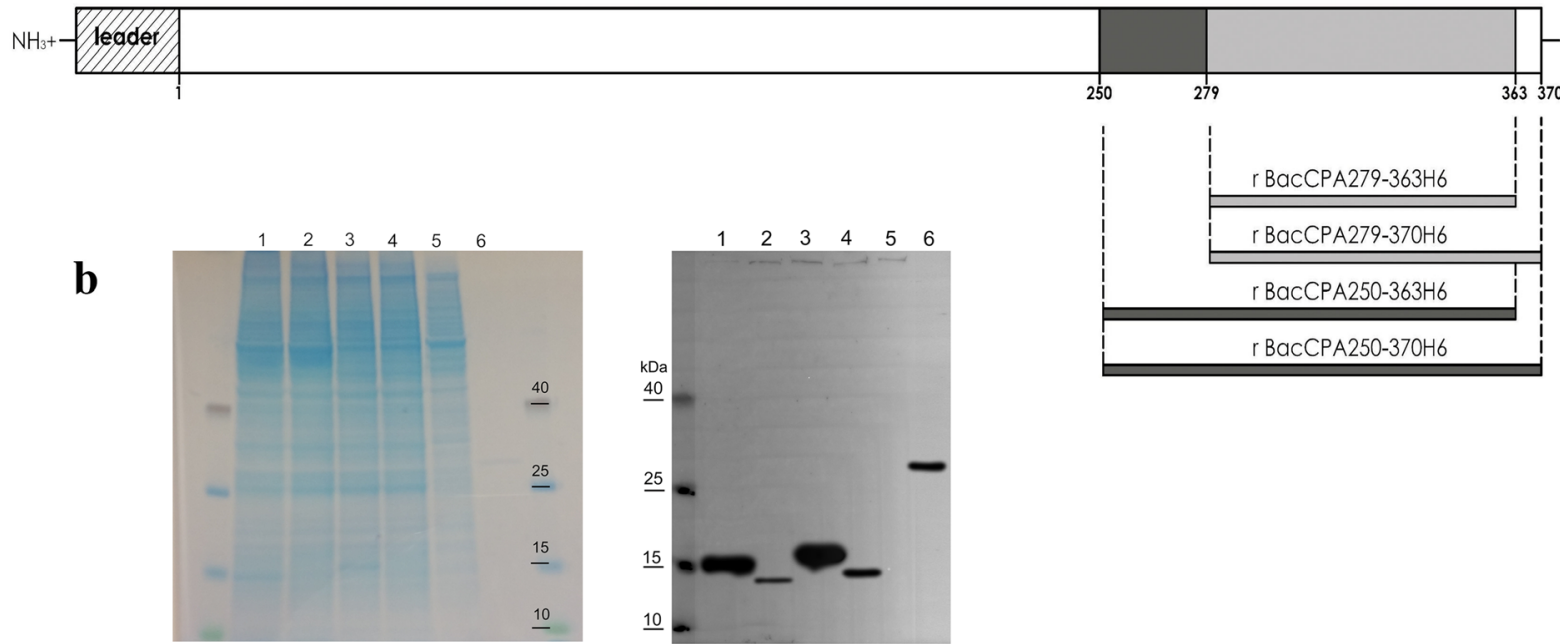

Fig. 3 Schematic representations and analysis via Western blot of the truncated recombinant rBacCPAH6 toxins. a The scheme were drawn approximately on scale, with amino acids numbered according to their positions in the CPA. Leader peptide (amino acids 1-28) were depicted as shown. The deleted forms of rBacCPAH6 were represented by bars. $\mathbf{b}$ Equal quantity of the cellular lysate of each sample harvested $72 \mathrm{~h}$ post infection, was loaded, electrophoresed on 12\% SDS-PAGE gels and stained with Coomassie blue and analysed in Western blot using an anti-His6HRP conjugated MAb. Lane 1: rBacCPA250-363H6 (approximately 15 kDa); lane 2: rBacCPA279-363H6 (approximately 11 kDa); lane 3: rBacCPA250370H6 (approximately $16 \mathrm{kDa}$ ); lane 4: rBacCPA279-363H6 (approximately $12 \mathrm{kDa}$ ); lane 5: cellular lysate of Sf21 uninfected cells (negative control); lane 6: $100 \mathrm{ng}$ of purified rCPB2 $\Delta$ 1-25-His6 (His6 positive control). The protein molecular weight marker is reported

using different concentrations of full-length PLC as standards (from 0.5 to $5 \mu \mathrm{g}$ ), the radial diffusion diameter varied between 13 to $23 \mathrm{~mm}$. The culture supernatants of different $C$. perfringens strains were tested and only in three strains the CPA toxin activity was detected as $3010^{-3} \mathrm{U} / \mathrm{ml}$. To determine whether the MAb 318F11B7 and the immune serum obtained against the rBacCPA250-363H6 proteins could neutralize the phospholipase activity of full-length PLC toxin, serially diluted antisera and increasing

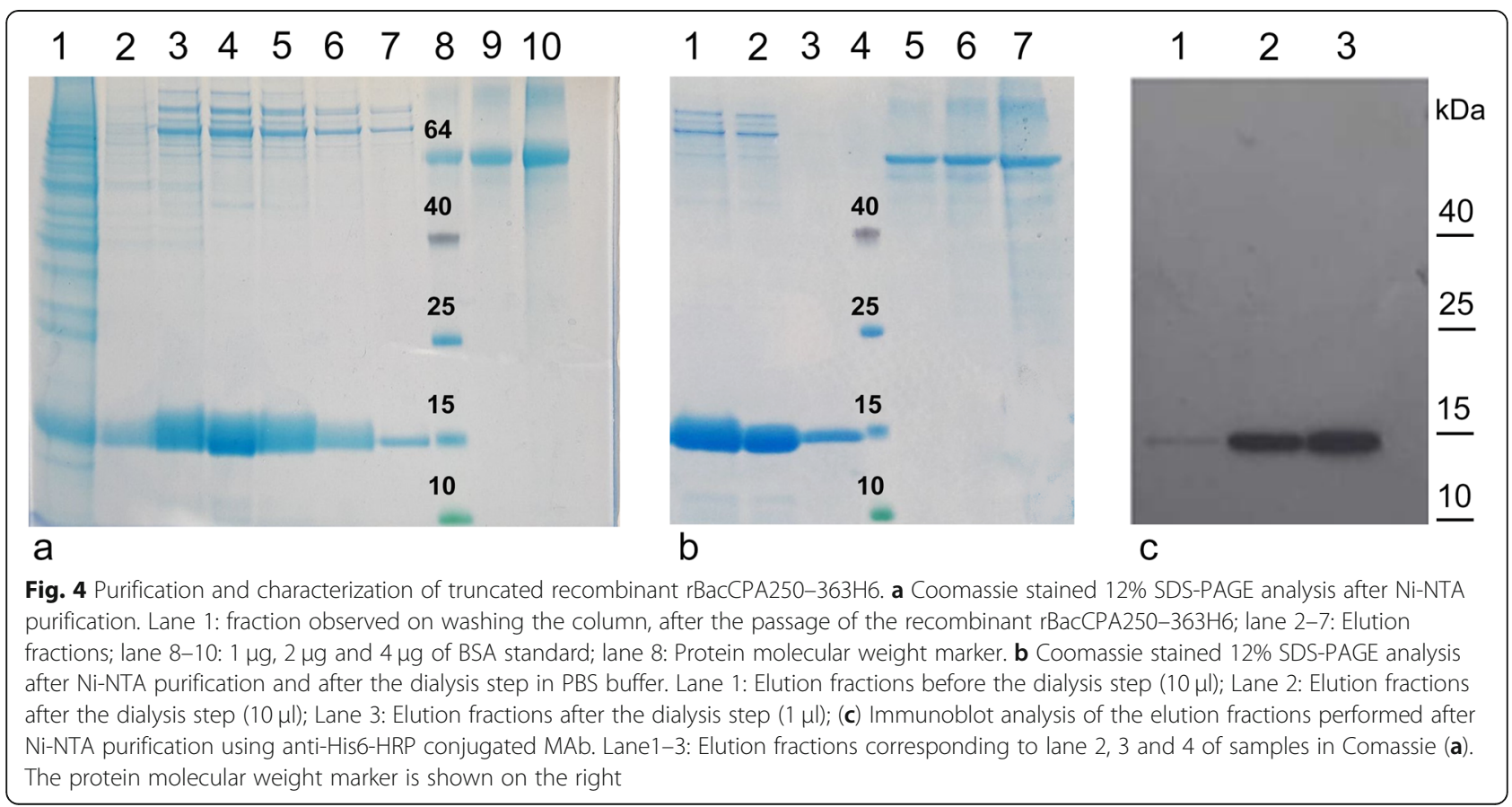




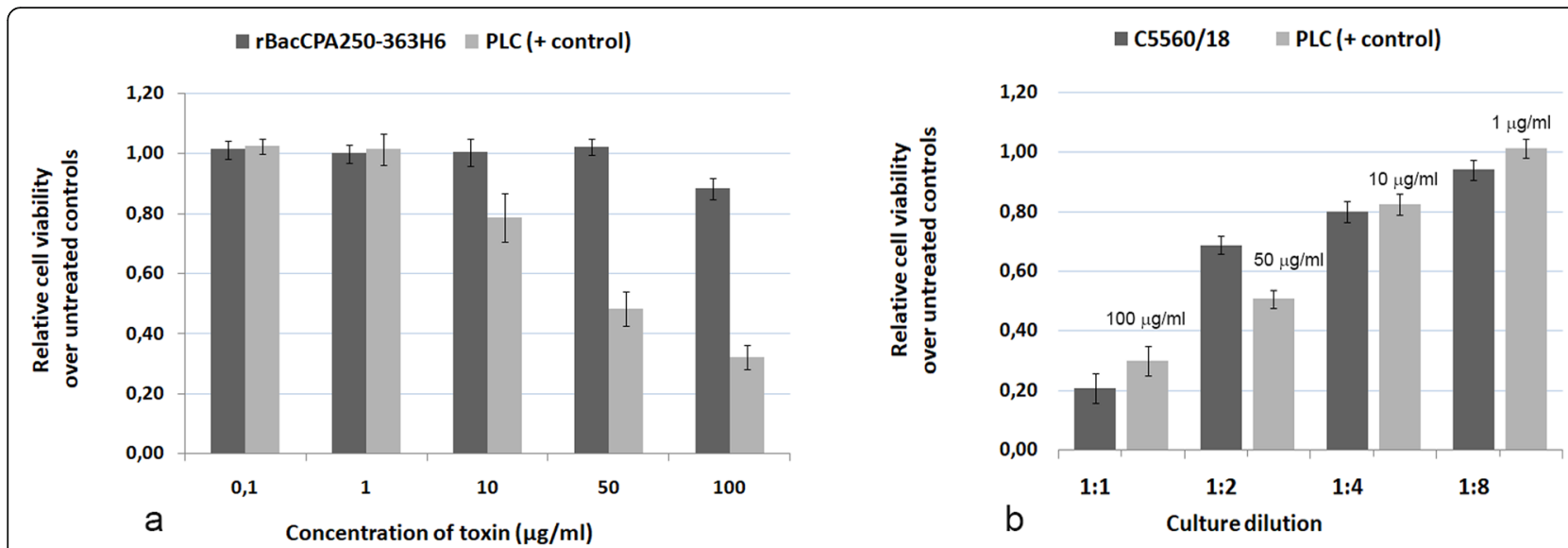

Fig. 5 Cytotoxicity of rBacCPA250-363H6 in CaCo-2 cells. Cells were treated as described in the methods section with rBacCPa250-363H6, PLC and culture supernatant of C. perfringens C-5560/18 strain. a The viability of cells, as determined by the MTS assay, after treating cells with indicated concentrations of rBacCPA250-363H6 and PLC toxins and (b) with a serially diluted solution of the supernatant of C. perfringens C-5560/ 18 strain. The data represent the mean of three independent experiments

concentrations of MAbs were incubated with $1 \mu \mathrm{g}$ of PLC and tested using the EYDT assay. When the antisera of rBacCPA250-363H6 were used at a final dilution of up to $1: 80$, the PLC activity was completely neutralised, instead, MAb 318F11B7 was unable to neutralise the activity of PLC at all the tested concentrations (Fig. 6).

\section{Characterization of PAbs and MAbs}

Two polyclonal and eight monoclonal antibodies were obtained against the truncated recombinant protein
rBacCPA250-363CPAH6. The immunogenicity of the protein was evidenced by the seroconversion of animals and evaluated by an indirect ELISA test; additionally, the reactivity of PAbs and MAbs was evaluated using an ELISA test (data not shown) and immunoblot assay (Fig. 7), conducted using the truncated rBacCPa250-363H6, full-length PLC, and $C$. perfringens culture supernatants as antigens.

The resultant MAbs and PAbs recognized an immunogenic band with a molecular weight of $15 \mathrm{KDa}$ from the lane containing truncated rBacCPA250-363H6 and a

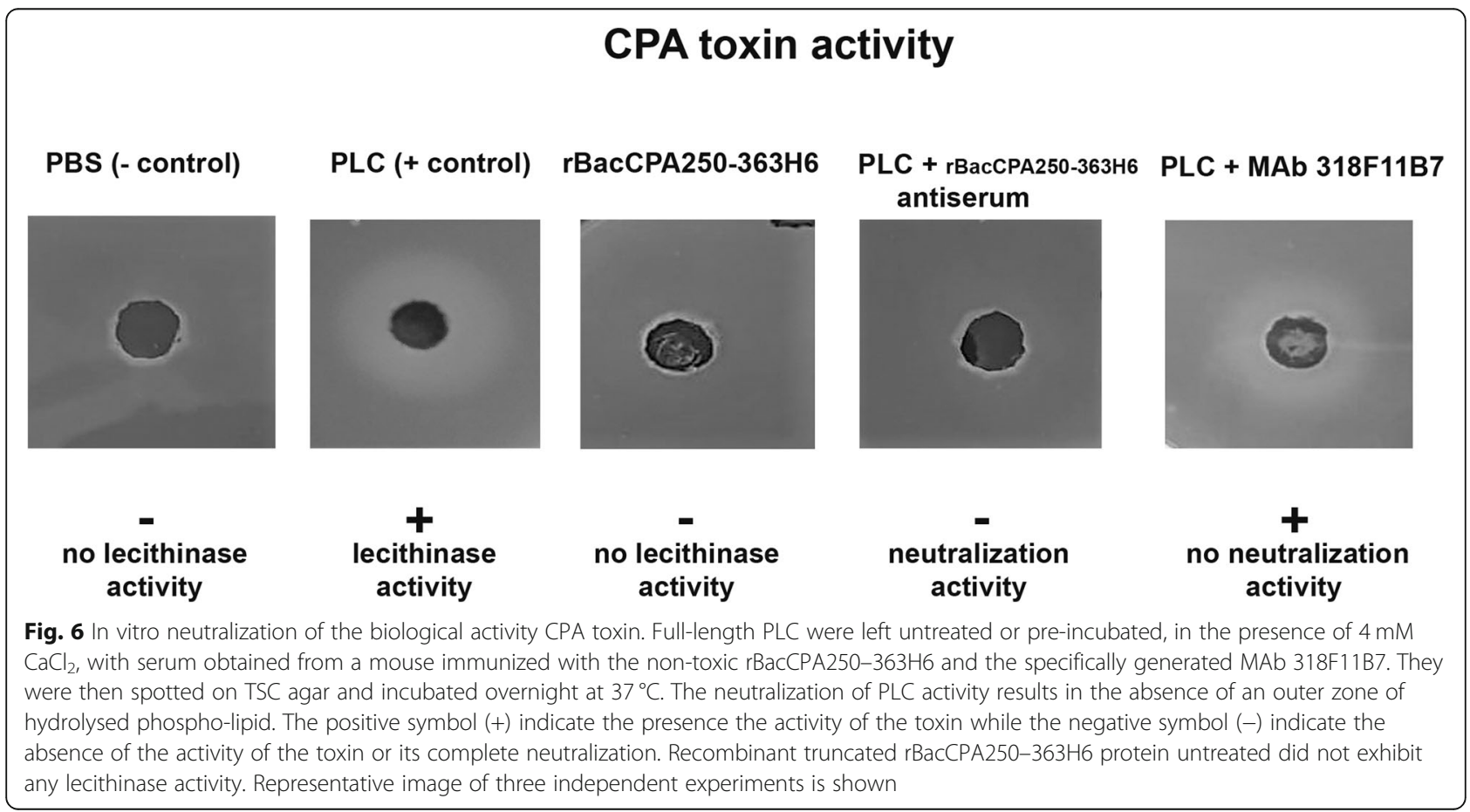




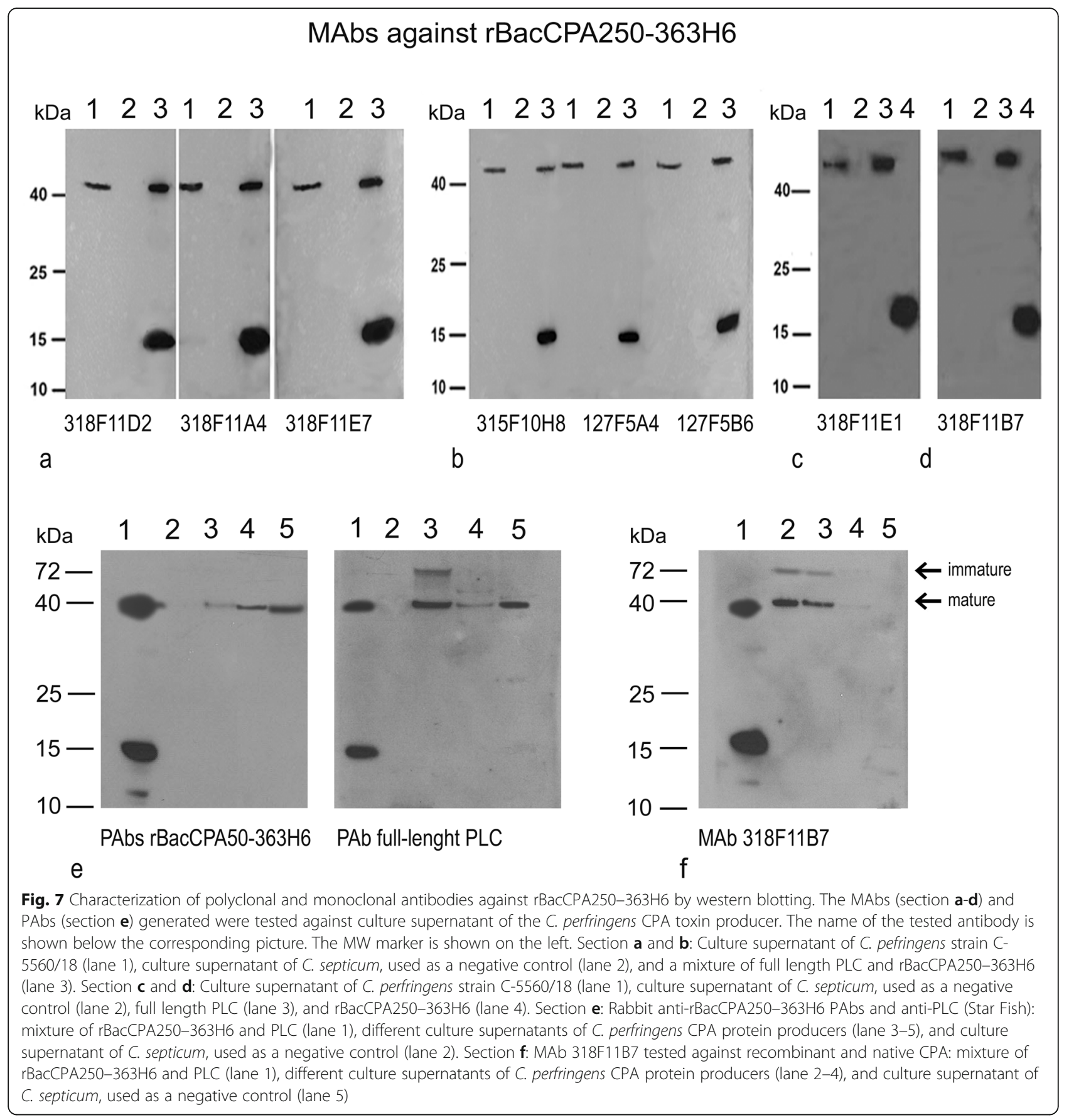

band with a size of $43 \mathrm{KDa}$ corresponding to the fulllength PLC and native CPA toxin in culture supernatants. The antibody specificity was tested using a $C$. septicum culture. Different levels of reactivity were observed among the eight monoclonal antibodies obtained: the MAbs315F10H8, 127F5A4 and 127F5B6 showed moderate reactivity, while the remaining five MAbs, i.e., 318F11D2, 318F11E7, 318F11A4, 318F11B7, and 318F11E1 showed strong reactivity in the western blot towards r250-363CPA His6 and native PLC
(Fig. 7 a-d). Fresh culture supernatants of different $C$. perfringens strains were tested using the MAb 318F11B7 (Fig. 7f), and in addition to the expected band at $43 \mathrm{KDa}$, another high molecular weight band (about 70-80 KDa) was observed, whose presence was probably attributable to a precursor or dimeric forms of native CPA. In Fig. 7e, anti-rBacCPA250363H6 PAbs and a polyclonal commercial Rabbit Anti-Phospholipase $\mathrm{C}$ were tested to compare them. All the polyclonal antibodies highlighted the presence 
of the recombinant protein $\mathrm{r} 250-363 \mathrm{CPAHis} 6$ and wild-type CPA protein at the same height as the PLC. MAb 318F11B7 exhibited the ability to neutralize the cytotoxicity of full-length PLC in CaCo- 2 cells. For the in vitro neutralization assay, 1x CT50 of PLC toxin $(50 \mu \mathrm{g} /$ $\mathrm{ml}$ ) was pre-incubated with diluted sera and different concentrations of MAbs at $37^{\circ} \mathrm{C}$ for $1 \mathrm{~h}$, and the mixture was then applied to the cells. The MTS assay results demonstrated that cells were only partially protected from the cytotoxicity of PLC. In the experimental conditions adopted, the use of merely100 $\mu \mathrm{g} / \mathrm{ml}$ of MAb resulted in PLC toxicity of up to $14 \%$, as compared to that in untreated control cells (data not shown).

\section{Discussion}

Clostridial myonecrosis, also known as gas gangrene, is a devastating histotoxic infection caused in humans and animals by $C$. perfringens strains. The high incidence, extensive morbidity, and high lethality rate, associated with Clostridiosis infections represents a serious concern for livestock, as it is responsible for significant economic losses that are particularly linked to a high level of neonatal mortality. Due to the rapid course of the disease, curative treatment is not possible; therefore, vaccination is the best prophylactic measure for this disease. The virulence of $C$. perfringens is attributable to the presence of its several extracellular toxins. The CPA toxin is produced by all types of $C$. perfringens strains and is an important immunogenic antigen that is involved in the pathogenesis of enterotoxaemia, and in the induction of necrotic lesions in the calf intestinal loop model [19]. The role of the type A strain in enterotoxaemia is rather controversial and has been extensively debated. Recently, it was shown, that neutralizing antibodies raised against the native CPA form and formaldehyde inactivated toxoid provided protection against $C$. perfringens infections $[19,37]$. Although this was an efficient strategy, the use of the active toxin was not safe and formaldehyde inactivation was required, even though it reduced immunogenicity [38, 39], and a risk of residual toxicity and hypersensitivity was associated with the presence of residual formaldehyde. The production of traditional clostridial vaccines involves the detoxification, purification, and antigen concentration steps; the potency of these vaccines varied from batch to batch and biosafety measures were required to manage the $C$. perfringens culture. In recent years, owing to the development of new genetic techniques, and the increased adoption of tridimensional studies and structural vaccinology, researchers have focused on developing more methods of producing recombinant proteins for use in veterinary vaccines. Studies of tridimensional structures and the functional characterization of the CPA toxin revealed the presence of two separate domains, a catalytic $\mathrm{N}$-terminal domain, and a smaller membrane- binding C-terminal domain. Only the latter is immuneprotective, in fact, Nagahama et al. demonstrated that mice immunized with GST-CP251-370 and GST-CP281-370 provided protection against the lethal effects of alpha toxin [18] and also ensured the survival of animals injected with $10 \mathrm{LD}_{100}$ doses of viable C. perfringens type A [17]. Recently, Shreya et al. reported that the immunization of mice with a bivalent chimerical protein Cpae (composed of the C-domains of CPA-toxin and enterotoxin CPE) resulted in a substantial level of protection against C. perfringens type A toxaemia [40]. Therefore, a C-terminal domain lacking in any enzymatic and toxin activity might be the principal immunogen of an alpha-toxin vaccine [19]. The reasons why the $\mathrm{C}$-terminal domain acts as a protective immunogen are not completely clear, but it is possible that an antibody against this domain had blocked the initial membrane-binding event [37].

In this study, several truncated forms of the CPA toxin (truncated rBacCPAH6) were generated for the first time in a heterologous expression system, such as Sf21 insect cells, using baculoviruses. The baculoviruses were able to produce the truncated rBacCPA279-363H6, rBacCPA279370H6, rBacCPA250-363H6, and rBacCPA250-370H6 proteins, all lacking the $\mathrm{N}$-terminal domain and the 28 amino acids (aa) of the putative signal sequence. The choice to use these new attenuated recombinant viruses (produced using the flashBAC system) guarantees robustness, costeffectiveness, high levels of expression, and a higher degree of biosafety.

Previous studies have shown that the expression levels of exogenous genes in baculovirus-infected insect cells were increased significantly in the presence of specific leader sequences [23, 41]. Hence, an initial investigation was performed to determine the level of expression of the rBacCPA279-363H6 protein that infected S21 cells, using three baculoviruses that differed with regard to the absence and presence of the Kozak sequence and the presence of $L 21$ leader sequences upstream of the start codon. Figure 1 shows that the Kozak sequence and especially $L 21$ leader sequences are essential for enhancing the expression of recombinant proteins. Moreover, studies performed to determine the optimal medium and infection conditions demonstrated that Ex-cell420 was the most suitable growth medium for maintaining viable the infected cells for at least three days (Fig. 2). The baculovirus expression system is often chosen for its ability to enable post-translational modifications to be made, such as those involving $\mathrm{N}$-glycosylation [42]; hence, an analysis of the amino acid sequence of the C-terminal domain of the CPA toxin was performed by the NetNGlyc 1.0 server. The results of this analysis predicted the presence of a hypothetical $\mathrm{N}$ glycosylation site at Asn-XaaSer/Thr, between the aa residues 364 to 370; thus, in order to avoid undesired glycosylation, this region was 
also removed in two constructs (rBacCPA279-363H6 and rBacCPA250-363H6). However, none of the four truncated recombinant $\mathrm{rBacCPAH6}$ proteins (all generated from baculoviruses containing the $L 21$ signal) were glycosylated, in fact, no increase in electrophoretic mobility was observed and the western blot analysis revealed the presence of immune-reactive bands with expected molecular weights of $11,12,15$, and $16 \mathrm{KDa}$ (Fig. 3). Under the same infection conditions, expression of two proteins with the amino acid residue 279 (rBacCPA279-363H6 andrBacCPA279-370H6) at the start of the sequence was observed to be very low, as compared to that of proteins containing the aa residue 250 (rBacCPA250-363H6 and rBacCPA250-370H6) at the start of the protein sequence. The recombinant rBacCPAH6 proteins lacked all the $\mathrm{N}$-terminal regions and the signal sequence, which represented by the first 28 amino acids, and were intracellular proteins occurring in the cellular lysates; in contrast, native CPA was present in the culture supernatant of $C$. perfringens. In addition, the best results were achieved in terms of production, satisfactory yield, and purity of the rBacCPA250-363H6 protein, when the cellular lysate was subjected to Ni-NTA His-select-affinity chromatography under denaturing conditions. As suggested for other recombinant proteins, such as CPB2 [24], this feature could be explained with respect to the folded protein by the significant exposure of the $\mathrm{C}$-terminal $6 \mathrm{xHis}$ tag of the denatured antigen. As shown in Fig. 4, Coomassie stained SDS-PAGE and immunoblotting analysis confirmed the high degree of purity (more than 85\%), specificity, and integrity of the protein.

Previous studies have established that the alpha toxin has cytotoxic effects on bovine endothelial cells, acting in synergistic effect with PFO, in fact, almost all cells detached after exposure to supernatant of the wild-type gas gangrene C. perfringens strain [43]. Endothelial cells form a vital barrier that controls the exchange of cells, macromolecules and fluids between the vascular lumen and the surrounding tissue. Disruption of the endothelial barrier leads to increased vascular permeability along with tissue edema and hemorrhage. CPA stimulate leucocyte adherence, probably by increasing vascular leucostasis and local ischemia [6]. The human enterocyte-like $\mathrm{CaCo}-2$ cell line has been used extensively over the last twenty years as a model of the absorptive and defensive properties of the intestinal mucosa $[44,45]$. Shreya et al. has demonstrated that recombinant Cpae chimera it bound to $\mathrm{CaCo}-2$ cell membrane but did not shown any toxicity [40]. We evaluated the cell viability of $\mathrm{CaCo}-2$ cells treated with the truncated recombinant CPA and full-length PLC proteins, and compared them with that of untreated and positive controls, in order to assess the percentage of metabolically active cells. Cytotoxicity studies were performed on intestinal epithelial cell lines using rCPA250-363H6, and they confirmed that this antigen, which was produced in baculovirus systems, was non-toxic, in comparison to the full-length PLC and native toxin present in $C$. perfringens supernatant. In fact, no changes were observed in the morphological traits of CaCo-2 cells and a minimal cytotoxicity (about 10\%) was reported after the MTS assay was performed using truncated recombinant CPA proteins present at a concentration of up to $100 \mu / \mathrm{ml}$. Instead, $\mathrm{CaCo}-2$ cell damage was observed after the confluent monolayer of cultured cells came into contact with $10 \mu \mathrm{g} / \mathrm{ml}$ of the full-length PLC or a culture supernatant that was diluted up to four times. The data were in accordance with the results obtained for the CPB2 atypical recombinant protein, which was expressed in baculoviruses [24].

The non-toxic recombinant rBacCPA250-363H6 protein purified under denaturing conditions was used to generate polyclonal and monoclonal antibodies (Fig. 7). Eight MAbs and two PAbs were obtained, and all of them recognized the truncated recombinant CPA (15 $\mathrm{KDa}$ ), full-length PLC, and native CPA toxin secreted in culture supernatants $(43 \mathrm{KDa})$, in the Western blot (Fig. 7a-e). MAbs showed high specificity and were unreactive against C. septicum culture supernatants. As showed in Fig. 7f, in addition to the predominant, mature form of $\mathrm{CPA}$, the MAb 318F11B7 recognized a reactive band at a higher molecular weight (around 70-80 KDa), which could be attributed to dimeric forms of native CPA or precursor proteins with a signal sequence before posttranslational processing that had been secreted in the $C$. perfringens supernatant, as suggested by Leslie et al. [46].

The neutralizing ability of the generated MAbs and mouse antisera was also tested through in vitro assays. Preliminary results showed that MAb 318F11B7 exhibited a partial ability to neutralize the cytotoxicity of full-length PLC in CaCo- 2 cells. Under the experimental conditions used, the MAb resulted in a restoration of $14 \%$ cell viability only when a high concentration $(100 \mu \mathrm{g} / \mathrm{ml})$ of the MAb was used, as compared to that of the cells exhibiting toxicity with PLC and the untreated control (data not shown). This is in accordance with the findings of the study performed by Goossens et al., which found that $C$. perfringens induced endothelial cytotoxicity observed in vitro was very weakly neutralized by $\mathrm{C}$-terminal fragment antisera [19]. Other researchers suggested that protection against the full length CPA toxin in vivo required only low molar ratios of neutralizing antibodies, whereas greater antibody to toxin molar ratios might be required to neutralise the cytotoxicity of PLC in vitro [32]. 
Alpha-toxin is a phospholipase $\mathrm{C}$ (lecithinase) that is capable of binding to the mammalian cell membrane in vivo, and cleaving membrane-bound phosphatidylcholine (or sphingomyelin) to produce phosphocholine and diacylglycerol (or ceramide). According to Moreau et al. [47], to maximize its activity, zinc is required for substrate hydrolysis and the calcium ion is essential for the binding of CPA toxin to the phospholipid monolayer, at concentrations of approximately $5 \mu \mathrm{M}$ and $5 \mathrm{mM}$, respectively $[12,48]$. The biological activity of CPA could be determined by an in vitro EYDT assay based on Nagler's reaction. The non-toxic rBacCPA250-363H6 protein did not exhibit any lecithinase activity on TSC agar at all the concentrations tested, as compared to that of the native, full length PLC, which was used as a standard. Nevertheless, the antiserum against the recombinant C-terminal protein showed the ability to completely neutralize the PLC toxin activity in vitro (Fig. 6). The same inhibition was not observed with the use of MAb 318F11B7. In a recent study carried out in bovine enterotoxemia strains, was shown an activity of alpha toxin below the detection limit of $15.610^{-3} \mathrm{U} / \mathrm{ml}$ and that were not significantly different from levels produced by strains isolated from healthy calves [29]. We detected an increased CPA activity only in the culture supernatants of three C. perfringens strains originating from enterotoxoemia cases and this in accordance with hypothesis that, a hither to unknown, C. perfringens virulence factor might be involved in the pathogenesis of calf enterotoxemia.

The polyclonal and monoclonal antibodies generated against rBacCPA250-363H6 were also characterized in an immune-enzymatic assay. In indirect ELISA, these antibodies recognized the recombinant rBacCPAH6 and full length PLC standard proteins, but showed a very low reactivity towards the native CPA observed in $C$. perfringens culture supernatants. These preliminary results, in combination with the good reactivity observed in the Western blot, suggested that MAbs target direct to linear epitopes, probably hidden in the native form of the toxin. This could be attributed to the purification of the antigen in denaturing conditions. In the reduced form, the protein might lack conformation-dependent epitopes, and steps to achieve refolding do not guarantee that the epitopes can be recovered on the protein structure. Some authors attributed the reduced reactivity of the antisera raised against the $\mathrm{C}$-terminal domain to the presence of the tag, which was generally inserted in the recombinant protein to make the purification process easier [19]. This hypothesis could be proven for the GST tag, after the eventual distortion of the conformation of the toxin, but it is difficult to apply it to the His tag, because it is smaller than GST, and is less likely to influence the conformation of CPA. In accordance with other studies, where recombinant C-terminal domains of alpha toxin were generated in prokaryotic cells, we reported a $\mathrm{N}$-terminal truncated $\mathrm{rBacCPA} 250-363 \mathrm{H} 6$ protein produced in eukaryotic system that is enzymatically inactive; and though its lecithinase activity is drastically reduced and its toxicity is abolished, it maintains its antigenic proprieties [48]. Because of these characteristics, it is a promising candidate for the development of a new recombinant protein vaccine. After combining data from different studies conducted in different animal species with regard to the role of CPA toxin in enteric diseases, $\mathrm{CPA}$ emerged as an essential toxin, but the unique use of anti-CPA toxin antibodies is inadequate for the complete neutralization of $C$. perfringens type Aassociated enteric disorders. Therefore, only an ideal multivalent vaccine comprising the recombinant $\mathrm{C}$ terminal domain of CPA toxin, other toxins, and additional virulence factors might be efficacious for protecting against type A toxaemia.

\section{Conclusion}

Collectively, in the present study, we first generated a recombinant baculovirus that expressed the $\mathrm{C}$-terminal region of the CPA toxin of Clostridium perfringens. In the baculovirus, a $L 21$ leader sequence was inserted to enhance the expression of recombinant proteins. The rBaccCPA250-363H6 His-tagged protein was efficiently purified and it was confirmed that its presence did not result in any cytotoxicity and biological activity in the CaCo- 2 cells and EYDT test, respectively. The specific polyclonal and monoclonal antibodies that were developed recognized the truncated recombinant CPA toxin, full length PLC, and native CPA in the Western blot and preliminary ELISA test. Further studies will be conducted for optimizing their use in immune-enzymatic assays. MAbs and antisera showed the ability to neutralize the lecithinase activity of the PLC toxin. Finally, the availability of these biologicals could contribute to the development of diagnostic assays and/or new recombinant protein vaccines.

\section{Abbreviations \\ aa: Amino acids; CPA: C. perfringens alpha toxin; DTT: Dithiothreitol; ELISA: Enzyme-linked Immunosorbent Assay; EYDT: Egg yolk diffusion test; FBS: Foetal bovine serum; MAb: Monoclonal antibody; MW: Molecular weight; ON: Overnight; PCR: Polymerase chain reaction; PLC: Phospholipase C; rBacCPA250-363H6: Deleted/truncated recombinant C-terminal 6xHis- tagged CPA toxin produced in baculovirus; RT: Room temperature; SDS- PAGE: Sodium dodecyl sulphate-polyacrylamide gel electhrophoresis}

\section{Acknowledgements}

The authors thank Canonico Giulio for his technical assistance, Dr Claudia Colabella and Dr Francesca Romana Masacci for discussion during the revision steps and Dr Rudy Trapassi for his support and help in preparing figures. 


\section{Ethics approval and consent to partecipate}

This article does not contain any studies with human participants or animals performed by any of the authors. Animal experimentation to obtain the PAbs and MAbs against the truncated recombinant protein rBacCPA250363CPAH6 was entrusted to the PRIMM Biotech Company (Dosson di Casier, Treviso, Italy) that offer this custumer service and produce biologicals and declares to operate in compliance to Good Laboratory Practice and Standard Operating Procedures of the facility and D. LGS 4 March 2014, No. 26 (Italian transposition of Directive 2010/63 EU) on the protection of animals used for scientific purposes.

\section{Declaration statements}

Not applicable.

\section{Authors' contributions}

KF and ADG conceived, designed the experiments; KF, MP, ADP, LA performed experiments; MC, GS, SC, ADP commented on and revised manuscript; KF and LA were involved in data analysis; KF interpreted the experiments and drafted the manuscript. MC was the head of research program. All authors read and approved the final version of the manuscript.

\section{Funding}

This work was supported by a research Grant from the Italian Ministry of Health Code RC IZSUM 09/14. No funding body had any role in the design of the study and interpretation of data and in writing the manuscript. These funds were used for collection of materials (primers, enzymes, flashBAC system, cell lines, MTS assay) and analysis of data.

\section{Availability of data and materials}

The data and the materials produced are available from the corresponding author after reasonable request and signing a material transfer agreement.

\section{Competing interests}

The authors declare that they have no competing interests.

Received: 12 April 2019 Accepted: 20 December 2019

\section{Published online: 28 January 2020}

\section{References}

1. Rood Jl, Adams V, Lacey J, Lyras D, BA MC, Melville SB, et al. Expansion of the Clostridium perfringens toxin-based typing scheme. Anaerobe. 2018.

2. McClane BA, Rood Jl. Clostridial Toxins Involved in Human Enteric and Histotoxic Infections. In: Clostridia: Biotecnology and Medical Application; 2005. p. 169-209.

3. Uzal FA, Freedman JC, Shrestha A, Theoret JR, Garcia J, Awad MM, et al. Towards an understanding of the role of Clostridium perfringens toxins in human and animal disease. Future Microbiol. 2014;9(3):361-77.

4. Flores-Díaz M, Alape-Girón A. Role of Clostridium perfringens phospholipase C in the pathogenesis of gas gangrene. Toxicon 2003;42(8):979-986.

5. Awad MM, Ellemor DM, Boyd RL, Emmins JJ, Rood Jl. Synergistic effects of alpha-toxin and Perfringolysin $\mathrm{O}$ in Clostridium perfringens-mediated gas gangrene. Infect Immun. 2001;69(12):7904-10.

6. Uzal FA, Vidal JE, McClane BA, Gurjar AA. Clostridium Perfringens toxins involved in mammalian veterinary diseases !2009-08-24 !2009-09-11 !201003-09 ! Open Toxinology J. 2010;3(2):24-42.

7. Lyristis M, Bryant AE, Sloan J, Awad MM, Stevens NIT, D.L. RJI. Identification and molecular analysis of a locus that regulates extracellular toxin production in Clostridium perfringens. Mol Microbiol. 1994;12(5):761-77.

8. Ohtani K, Shimizu T. Regulation of toxin gene expression in Clostridium perfringens. Res Microbiol. 2015;166(4):280-9.

9. Adachi K, Ohtani K, Kawano M, Singh RP, Yousuf B, Sonomoto K, et al. Metabolic dependent and independent pH-drop shuts down VirSR quorum sensing in Clostridium perfringens. J Biosci Bioeng. 2018;125(5):525-31.

10. Odendaal MW. Purification of the alpha toxin of clostridium perfringens type a me e. Onderstepoon J vet Res. 1987;54:39-43.

11. Titball RW, Naylor CE, Basak AK. The Clostridium perfringens alpha-toxin. Anaerobe. 1999;5(2):51-64

12. Naylor CE, Jepson M, Crane DT, Titball RW, Miller J, Basak AK, et al. Characterisation of the calcium-binding C-terminal domain of Clostridium perfringens alpha-toxin. J Mol Biol. 1999;294(3):757-70.
13. Eaton JT, Naylor CE, Howells AM, Moss DS, Titball RW, Basak AK. Crystal structure of the $\mathrm{C}$. perfringens alpha-toxin with the active site closed by a flexible loop region. J Mol Biol. 2002;319(2):275-81.

14. Oda M, Terao Y, Sakurai J, Nagahama M. Membrane-binding mechanism of Clostridium perfringens alpha-toxin. Toxins (Basel). 2015;7(12):5268-75.

15. Navarro MA, McClane BA, Uzal FA. Mechanisms of action and cell death associated with Clostridium perfringens toxins. Toxins (Basel). 2018;10(5):1-21.

16. Jepson M, Howells A, Bullifent HL, Bolgiano B, Crane D, Miller J, et al. Differences in the carboxy-terminal (putative phospholipid binding) domains of Clostridium perfringens and Clostridium bifermentans phospholipases $C$ influence the hemolytic and lethal properties of these enzymes. Infect Immun. 1999;67(7):3297-301.

17. Williamson $E D$, Titball RW. A genetically engineered vaccine against the alpha-toxin of Clostridium perfringens protects mice against experimental gas gangrene. Vaccine. 1993;11(12):1253-8.

18. Nagahama M, Oda M, Kobayashi K, Ochi S, Takagishi T, Shibutani M, et al. A recombinant carboxy-terminal domain of alpha-toxin protects mice against Clostridium perfringens. Microbiol Immunol. 2013.

19. Goossens E, Verherstraeten $S$, Valgaeren BR, Pardon B, Timbermont $L$, Schauvliege $S$, et al. The C-terminal domain of Clostridium perfringens alpha toxin as a vaccine candidate against bovine necrohemorrhagic enteritis. Vet Res. 2016;47(1):1-9.

20. Monturiol-Gross L, Flores-Díaz M, Campos-Rodríguez D, Mora R, RodríguezVega M, Marks $\mathrm{DL}$, et al. Internalization of Clostridium perfringens ??-toxin leads to ERK activation and is involved on its cytotoxic effect. Cell Microbiol. 2014;16(4):535-47.

21. Takagishi T, Takehara M, Seike S, Miyamoto K, Kobayashi K, Nagahama M. Clostridium perfringens a-toxin impairs erythropoiesis by inhibition of erythroid differentiation. Sci Rep. 2017;7(1):1-11.

22. MacFarlane MG, Knight $B C$. The biochemistry of bacterial toxins: the lecithinase activity of cl. Welchii toxins. Biochem J. 1941;35(8-9):884-902.

23. Sano K-I, Maeda K, Oki M, Maéda Y. Enhancement of protein expression in insect cells by a lobster tropomyosin cDNA leader sequence. FEBS Lett. 2002;532(1-2):143-6.

24. Serroni A, Magistrali CF, Pezzotti G, Bano L, Pellegrini M, Severi G, et al. Expression of deleted, atoxic atypical recombinant beta2 toxin in a baculovirus system and production of polyclonal and monoclonal antibodies. Microb Cell Factories. 2017;16(1):1-11.

25. Yoo HANS, Lee SUN, Park KY, Park YHO. Molecular typing and epidemiological survey of prevalence of Clostridium perfringens types by multiplex PCR. J Clin Microbiol. 1997;35(1):228-32.

26. Okabe A, Shimizu T, Hayashi H. Cloning and sequencing of a phospholipase C gene of Clostridiumperfringens. Biochem Biophys Res Commun. 1989; 160(1):33-9.

27. Titball RW, Hunter SE, Martin KL, Morris BC, Shuttleworth AD, Rubidge T, et al. Molecular cloning and nucleotide sequence of the alpha-toxin (phospholipase C) of Clostridium perfringens. Infect Immun. 1989 Feb;57(2): 367-76.

28. Rigby GJ. An egg-yolk agar diffusion assay for monitoring phospholipase C in cultures of Clostridium welchii. J Appl Bacteriol. 1981;50(1):11-9.

29. Goossens E, Verherstraeten S, Timbermont L, Valgaeren BR, Pardon B, Haesebrouck $F$, et al. Clostridium perfringens strains from bovine enterotoxemia cases are not superior in in vitro production of alpha toxin, perfringolysin $\mathrm{O}$ and proteolytic enzymes. BMC Vet Res. 2014; 10(1):1-7.

30. Natoli M, Leoni BD, D'Agnano I, Zucco F, Felsani A. Good Caco-2 cell culture practices. Toxicol In Vitro. 2012;26(8):1243-6.

31. Clark GC, Briggs DC, Karasawa T, Wang X, Cole AR, Maegawa T, et al. Clostridium absonum a-toxin: new insights into Clostridial phospholipase C substrate binding and specificity. J Mol Biol. 2003;333(4):759-69.

32. Neeson BN, Clark GC, Atkins HS, Lingard B, Titball RW. Analysis of protection afforded by a Clostridium perfringens a-toxoid against heterologous clostridial phospholipases C. Microb Pathog. 2007:43(4):161-5.

33. Zeng J, Song F, Yang Y, Ma C, Deng G, Li Y, et al. The generation and characterization of recombinant protein and antibodies of Clostridium perfringens Beta2 toxin. J Immunol Res. 2016;2016.

34. Lid ZL, Blaschek HP. Monoclonal antibody-based ELISA for detection of Clostridium perfringens Alpha-toxin. J Food Prot. 1996;59(6):621-5.

35. Harlow E, Lane D. Antibodies : a laboratory manual. Cold Spring Harbor Laboratory; 1988. p. 726. 
36. Fabio Malavasi Bargellesi Severi Antonio. Anticorpi monoclonali. Tecniche di base | Fabio Malavasi e Bargellesi Severi Antonio | Forum Service | 1992. Unilibro; 1992. $212 \mathrm{p}$.

37. Stevens $D L$, Titball RW, Jepson M, Bayer CR, Hayes-Schroer SM, Bryant AE. Immunization with the C-domain of a-toxin prevents lethal infection, localizes tissue injury, and promotes host response to challenge with Clostridium perfringens. J Infect Dis. 2004;190(4):767-73.

38. Titball RW. Gas gangrene: an open and closed case. Microbiology. 2005; 151(9):2821-8.

39. Goossens E, Verherstraeten S, Valgaeren BR, Pardon B, Timbermont L, Schauvliege $S$, et al. Toxin-neutralizing antibodies protect against Clostridium perfringens-induced necrosis in an intestinal loop model for bovine necrohemorrhagic enteritis. BMC Vet Res. 2016;12(1):1-8.

40. Shreya D, Uppalapati SR, Kingston JJ, Sripathy MH, Batra HV. Immunization with recombinant bivalent chimera r-Cpae confers protection against alpha toxin and enterotoxin of Clostridium perfringens type a in murine model. Mol Immunol. 2015;65(1):51-7.

41. Hills D, Crane-Robinson C. Baculovirus expression of human basic fibroblast growth factor from a synthetic gene: role of the Kozak consensus and comparison with bacterial expression. Biochim Biophys Acta. 1995;1260(1):14-20.

42. Shi $X$, Jarvis D. Protein N-glycosylation in the Baculovirus-insect cell system. Curr Drug Targets. 2007;8(10):1116-25.

43. Verherstraeten $\mathrm{S}$, Goossens E, Valgaeren B, Pardon B, Timbermont L, Vermeulen $\mathrm{K}$, et al. The synergistic necrohemorrhagic action of Clostridium perfringens perfringolysin and alpha toxin in the bovine intestine and against bovine endothelial cells. Vet Res. 2013;44(1).

44. Sambuy Y, De Angelis I, Ranaldi G, Scarino ML, Stammati A, Zucco F. The Caco-2 cell line as a model of the intestinal barrier: infuence of cell and culture-related factors on Caco-2 cell functional characteristics. Cell Biol Toxicol. 2005;21(1):1-26.

45. Artursson P, Palm K, Luthman K. Caco-2 monolayers in experimental and theoretical predictions of drug transport. Adv Drug Deliv Rev. 2012; 64(Suppl):280-9.

46. Leslie D, Fairweather N, Pickard D, Dougan G, Kehoe M. Phospholipase C and haemolytic activities of Clostridium perfringens alpha-toxin cloned in Escherichia coli: sequence and homology with a Bacillus cereus phospholipase C. Mol Microbiol. 1989;3(3):383-92.

47. Moreau H, Pieroni G, Jolivet-Reynaud C, Alouf JE, Verger R. A new kinetic approach for studying phospholipase C (Clostridium perfringens .alpha. toxin) activity on phospholipid monolayers. Biochemistry. 1988;27(7):2319-23.

48. Guillouard I, Alzari PM, Saliou B, Cole ST. The carboxy-terminal C2-like domain of the alpha-toxin from Clostridium perfringens mediates calciumdependent membrane recognition. Mol Microbiol. 1997 Dec;26(5):867-76.

\section{Publisher's Note}

Springer Nature remains neutral with regard to jurisdictional claims in published maps and institutional affiliations.

Ready to submit your research? Choose BMC and benefit from:

- fast, convenient online submission

- thorough peer review by experienced researchers in your field

- rapid publication on acceptance

- support for research data, including large and complex data types

- gold Open Access which fosters wider collaboration and increased citations

- maximum visibility for your research: over $100 \mathrm{M}$ website views per year

At BMC, research is always in progress.

Learn more biomedcentral.com/submissions 